\title{
Characteristics of nest cavities used by White-backed Woodpecker (Dendrocopos leucotos) in Hungary
}

\author{
Gerard GORMAN
}

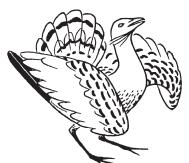

Received: September 17, 2021 - Revised: October 19, 2021 - Accepted: October 20, 2021

Gorman, G. 2021. Characteristics of nest cavities used by White-backed Woodpecker (Dendrocopos leucotos) in Hungary. - Ornis Hungarica 139-150. DOI: 10.2478/orhu-2021-0025

\begin{abstract}
The objective of this study was to document characteristics of cavities used for breeding by Whitebacked Woodpeckers Dendrocopos leucotos in Hungary. Twenty-five nest cavities were examined over a period of ten years (2011-2020). Five different tree species were used. The cavities were excavated at a mean height of $4.6 \mathrm{~m}$ and $2.2 \mathrm{~m}$ standard deviation and ranged from 2 to $8 \mathrm{~m}$. All cavities found were in the main trunks of trees with trunk diameters ranging between $35-55 \mathrm{~cm}$ with a mean of $41.6 \mathrm{~cm}$ and $5.6 \mathrm{~cm}$ standard deviation. A southerly orientation of cavity entrances prevailed with a mean direction of $189 \pm 74$ clockwise from north (median $180^{\circ} \mathrm{IQR}=113^{\circ}$ ). The results suggest that cavity entrance orientation was non-random.
\end{abstract}

Keywords: woodpecker, nest cavities, cavity location, cavity height, cavity entrance orientation, deadwood

Összefoglalás A tanulmány célja, hogy dokumentálja a fehérhátú fakopáncsok (Dendrocopos leucotos) fészekodúinak jellemzöit Magyarországon. A tíz év időtartam alatt (2011-2020) vizsgált huszonöt odú öt különböző fafajban volt, elhelyezkedésük magassága 2 és 8 méter között változott, átlagosan 4,6 22,2 m volt. A fák törzsátméröje 35-55

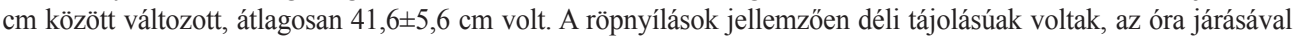
megegyezően $189 \pm 74^{\circ}$ irányban, ami arra utal, hogy az odúk bejárata nem véletlenszerủen helyezkedett el.

Kulcsszavak: fakopáncs, költőodú, az odú helye, odúmagasság, röpnyílás tájolása, holtfa

Independent Picid Researcher, Hungarian Woodpecker Working Group, MME Központ, 1121, Budapest, Költö utca 21, Hungary

e-mail: picidae.gerard@gmail.com

\section{Introduction}

The White-backed Woodpecker Dendrocopos leucotos is an Old-World picid, distributed within the Palearctic. Its range covers three eco-climatic regions: the temperate, Mediterranean and boreal zones. It occurs from Spain and France (the Pyrenees) in the west, central Italy (the Abruzzi) and the Balkans in the south, Scandinavia in the north and eastwards through Russia and Asia to Japan (Gorman 2014). The species is polytypic, with 11 (del Hoyo \& Collar 2014) or 12 (Gorman 2014) subspecies generally recognised. The nominate leucotos occurs in Hungary where this study was carried out. The south-western Palaearctic lilfordi subspecies is sometimes regarded as a valid phylogenetic species based on molecular species delimitation methods, gene flow analyses and differences in plumage (Pons et al. 2021). This taxon has been extensively studied and relevant data is included for comparison in this paper. 
White-backed Woodpecker inhabits a variety of forested habitats across its range, usually deciduous (Wesołowski 1995, Grangé et al. 2002), but also mixed deciduous-coniferous (Fernández \& Azkona 1996). In parts of Russia, forests dominated by conifers are sometimes inhabited (Dement'ev \& Gladkov 1966), but in general stands of pure conifer, such as plantations of Norway spruce Picea abies, are avoided (Hämäläinen et al. 2020). Ultimately, White-backed Woodpeckers are strongly associated with mature deciduous trees and deciduous deadwood. Numerous studies from across the range have shown that reasonably large areas of unmanaged old-growth forest with a high proportion of deadwood, standing and fallen, are required for both foraging and breeding (Håland \& Ugelvik 1990, Costantini \& Melletti 1992, Grangé 1993, 2016, Virkkala et al 1993, Hogstad \& Stenberg 1994, Bernoni 1995, Mikusiński \& Angelstam 1998a, 1998b, Frank 2002, Håpnes 2003, Melletti \& Penteriani 2003, Pavelka 2003, Garmendia et al. 2006, Czeszczewik 2009, Gerdzhikov et al. 2018, Schwaiger \& Lauterbach 2019, Urkijo-Letona et al. 2020, Bühler 2021). In Hungary, the species generally only occurs in hill forests where there are native deciduous tree species older than 60-70 years and a minimum volume of $20 \mathrm{~m}^{3} /$ ha of deadwood (Szmorad et al. 2018). Nevertheless, Whitebacked Woodpeckers will persist in managed forests if there is a natural, or close to natural regeneration, with sufficient rotting timber, mostly in forests where management is minimal (Aulén 1988, Aulén \& Carlson 1990).

The global population of the species is unknown but is considered to be large with the bulk of the population found in the eastern part of its range. European populations occupy around $35 \%$ of the global range, with a breeding population of $232,000-586,000$ pairs estimated. A preliminary estimate of the total world population size has been made of $1,320,000$ $3,350,000$ adult birds, although validation of this estimate is required (BirdLife International 2021). The European range is rather disjunct and in the west of the continent, this woodpecker is often localised and rare. Despite some local increases, populations have been declining for decades in several European countries, for example in Poland (Wesołowski \& Tomiałojć 1986), Sweden (Aulén 1988), Germany (Scherzinger 1990), Norway (Håland \& Ugelvik 1990), Finland (Virkkala et al. 1993, Martikainen et al. 1998), Spain (Fernández \& Azkona 1996) and Latvia (Krams 1998). Yet, the overall European trend is considered to be stable (Lanz et al. 2020). The main reasons for the decline of the species are the loss of old-growth deciduous forests and inappropriate forestry management (Carlson 2000, Håpnes 2003, Sabatini et al. 2018). The Red List of the International Union for Conservation of Nature (IUCN) categorises White-backed Woodpecker as Least Concern (BirdLife International 2021). Owing to the forest habitat types in which it thrives, the White-backed Woodpecker can be considered an umbrella species, as its occurrence is linked to the presence of many other species (flora, fauna and fungi) of high conservation concern (Roberge et al. 2008).

White-backed Woodpecker is the rarest and most range-restricted member of the Picidae family in Hungary, the only species from the nine that occur to be assigned 'Strictly Protected Species' status (Gorman et al. 2021). In Hungary, as elsewhere, intensive forest management, which often involves clear-cutting, fragmentation, felling of mature trees, removal of deadwood and the introduction of non-native tree species is a common problem (Szmorad et al. 2018). Logging in supposedly protected areas and even in the spring during the breeding season (pers. obs.), has resulted in a reduction in woodpeckers' numbers. The size of the Hungarian breeding 
population remains unclear, a recent estimation of between 260-670 pairs (Gorman et al. 2021) will be refined once an ongoing national survey is completed. Some studies of White-backed Woodpeckers have been conducted in Hungary, but none have focused on nest cavities.

Although White-backed Woodpeckers will occasionally create cavities in autumn and winter (Grangé et al. 2020), data were collected in the months of March, April and May as this is the period when cavity excavation is most prevalent. All woodpeckers tend to nest earlier when spring temperatures are high, but in Europe, White-backed Woodpeckers are usually the earliest breeders (Grangé et al. 2002, Wesołowski et al. 2021). Pairs tend to work on several new cavities each spring, but not all are finished. Old cavities are rarely re-used as nest sites but are used as roosts (Aulén \& Carlson 1990).

This study had five main aims as follows: (1) to determine tree species used; (2) to document cavity locations, whether on trunks or limbs and the health of nest trees; (3) to measure the height of cavity entrances above ground level; (4) to measure the trunk diameters at breast height (DBH) of trees with cavities; (5) to document the orientation of cavity entrances.

\section{Methods}

Woodpecker nest sites may be quantitatively described by examining the characteristics of the nesting tree (Hågvar et al. 1990). This study was restricted to nest cavities excavated and used by White-backed Woodpeckers in Hungary. The main aims of this study were to characterize cavity trees used by this species including the tree species, its state of decay,

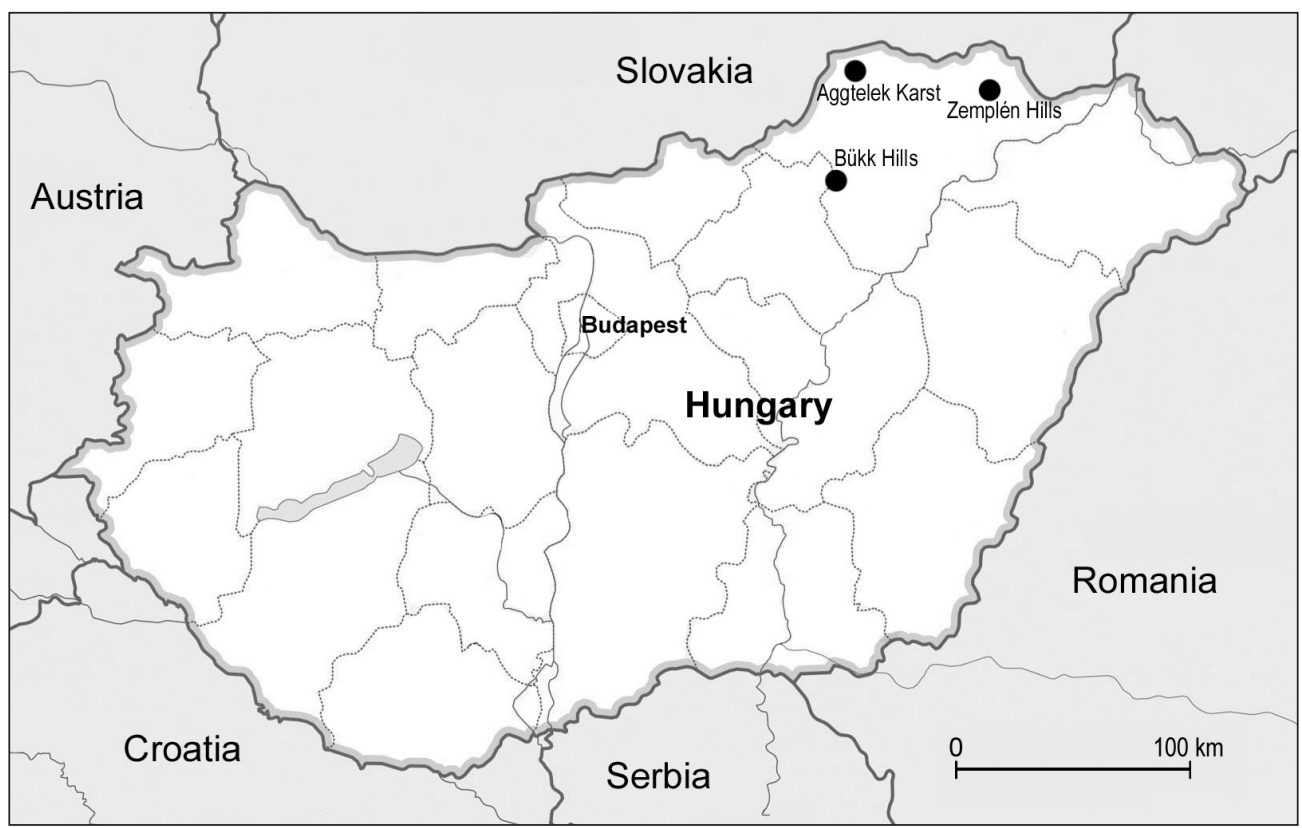

Figure 1. The three study areas in north-east Hungary

1. ábra A három vizsgálati terület ÉK-Magyarországon 
cavity locations (whether they were on trunks or limbs), cavity height, orientation of cavity entrances and the diameter of trees used. The study was carried out over a ten-year period, from 2011-2020 and conducted in three hill areas in the north-east of the country characterized by tracts of deciduous forested slopes, namely Aggtelek, Bükk and Zemplén (Figure 1). These hills are characterised by relatively low elevations, the highest peaks in each all being below 1,000 $\mathrm{m}$ above sea-level.

Cavities were searched for in forest habitats, visually searching known areas where the species had been observed previously. Cavities were located by observing the behaviour of the birds, such as courtship behaviour and seeing birds carrying food for nestlings, finding fresh woodchips below trees and by hearing persistent calling, drumming, tapping and the sounds made during excavation work. Cavity height was estimated using simple trigonometry. The diameter of cavity trees was calculated by means of the standard method of $\mathrm{DBH}$, with measurements taken using callipers at $1.3 \mathrm{~m}$ above the ground from the base of the trunk. Cavity orientation was calculated with a compass, using sixteen standard points (N, NNE, NE, ENE, etc.). The randomness of orientation was assessed using a Rayleigh test of uniformity (Pewsey et al. 2013) as implemented in the package 'circular' (version 0.4-3, Lund \& Agostinelli 2011) in R, (R Development Core Team 2015). This provides a statistic, $\mathrm{r}$, with value between 0 and 1 , where zero indicates a random distribution and 1 represents perfect alignment to one direction. The package also provides a mean orientation.

\section{Results}

A total of twenty-five active White-backed Woodpecker nest cavities were found during the study and their attributes and locations documented. All cavity trees were in forests dominated by deciduous trees. All cavities were newly excavated: none were from previous years that were being reused. New cavities can be recognized by their entrances having clean edges with no renewed tree growth, and light-coloured wood, and an abundance of fresh woodchips at the base of trees (Gorman 1995). Cavities were often located in trees close to those used in previous years. Cavity entrances were generally circular in shape, occasionally horizontally oval, however their dimensions were not measured.

Cavity trees: In this study, nests were found in just five tree species (number of occasions in brackets). All were broadleaved: beech Fagus sylvatica (12), hornbeam Carpinus betulus (10), wild cherry Prunus avium (1), ash Fraxinus excelsior (1) and pedunculate oak Quercus robur (1). While there was a clear dominance of two species (Table 1), beech (48\%) and hornbeam $(40 \%)$, this was not tested for selection by White-backed Woodpeckers due to lack of data on relative tree species availability from within the study area. Across their vast range Whitebacked Woodpeckers excavate their nest cavities in a variety of trees, however factors such as wood condition, location and general availability are more important than actual tree species. They do not seem to show any significant preference for particular tree species, rather they are only associated with specific trees locally. 
Cavity location: All cavities found were located in main trunks, positioned on foliage-free areas below canopy level, with an open fly path to the entrance. None were found in boughs or branches. All were in dead trees (snags) or in decaying sections of living trees. It was not always possible to verify the existence or extent of decay on all cavity trees, however visually it was obvious that twenty-two (88\%) were affected. Twenty of the total of twenty-five cavities ( $80 \%$ ) were located beneath a growth of tinder polypore Fomes fomentarius, twelve on beech, eight on hornbeam.

Cavity height: In this study, the heights of cavity entrances from the ground level varied between $2 \mathrm{~m}$ and $8 \mathrm{~m}$, with a mean of $4.6 \mathrm{~m}$ and a standard deviation of $2.2 \mathrm{~m}$.

Tree trunk width: The widest diameter (DBH) of a cavity tree was $55 \mathrm{~cm}$ and the narrowest $35 \mathrm{~cm}$. The most frequently documented diameter was $40 \mathrm{~cm}(5$ cavities: $20 \%$ ), with a mean of $41.6 \mathrm{~cm}$ and standard deviation of $5.6 \mathrm{~cm}$.

Cavity entrance orientation: In this study, a southerly orientation prevailed. Of the twenty-five cavities, thirteen $(52 \%)$ faced southwards (SE, SSE, S, SSW, SW). The most frequent alignments were SE and SW with four (16\%) cavities each. Five cavities faced westwards (WNW, W, WSW), four eastwards (E, ESE) and three northwards (NE, NW). The cavity orientation was non-random and appreciably biased toward the south (Rayleigh test $\mathrm{r}=0.37, \mathrm{P}=0.03$ ) with a mean direction of $189^{\circ}$ clockwise from north and $74^{\circ}$ standard deviation (median $180^{\circ} \mathrm{IQR}$ (inter-quartile range $\left.)=113^{\circ}\right)($ Figure 2$)$.

\section{Conclusions}

This paper summarises some characteristics of twenty-five nest cavities of White-backed Woodpeckers in Hungary. As the study was conducted over ten years and in several disjunct 
areas, it is unlikely that the cavities found were all created by the same individuals and thus the individual preferences of a few birds are unlikely to significantly bias the results presented here.

Cavities were found in five different tree species with two (beech and hornbeam) dominating but owing to the relatively small sample size and lack of data on relative tree species availability within the study area, no firm conclusions could be made. However, trees in other parts of the species' range might be compared. In the Western Pyrenees, France, from 43 nests documented in one study $97 \%$ were situated in beech (Grangé et al. 2002) and in another in the same region all but one from 76 were in beech, the exception being a nest in a fir

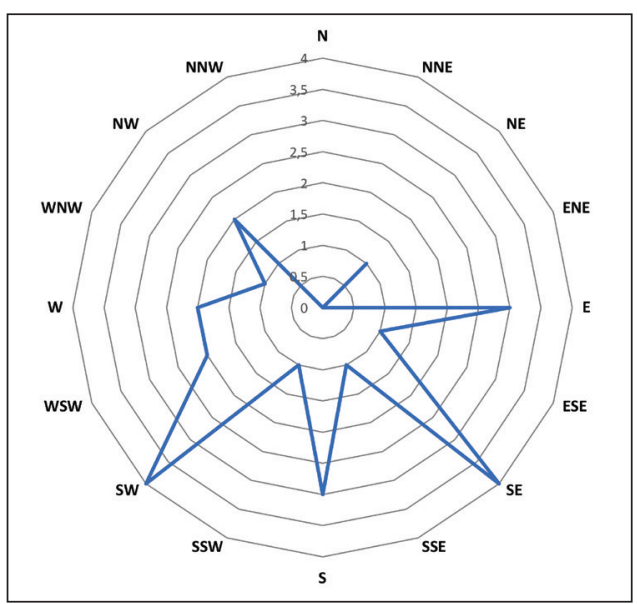

Figure 2. Orientation of White-backed Woodpecker cavity entrances as frequencies of cardinal points

2. ábra A fehérhátú fakopáncs odúk tájolása Abies spp. (Grangé 2009). In Navarra, Spain, all the nests in one study were also located in beech (Cárcamo et al. 2019). But in Fennoscandia, birches Betula spp. and particularly aspen Populus tremula are commonly used. Sometimes $90 \%$ of nest cavities are located in the latter soft wood species (Aulén 1988, Hogstad \& Stenberg 1994). In the Białowieża forest in Poland, alders Alnus are used in boggy parts of the forest and hornbeam Carpinus betulus and oaks Quercus spp. in drier areas (Wesołowski 1995).

The extremely strong use of White-backed Woodpecker in this study for nest sites in dead trees or dead parts of trees was consistent with most studies on this species carried out elsewhere (Stenberg \& Hogstad 1992, Hogstad \& Stenberg 1994, Krams 1998, Pavlík 1999, Grangé et al. 2002). However, one study in France documented that $77 \%$ of nesting trees were in a healthy state (Grangé 2009), and in an Italian study $40 \%$ of pairs nested in trees without evidence of decay (Melletti \& Penteriani 2003). Furthermore, in the same study, although the majority of nests (75\%) were in trunks below the canopy, $25 \%$ were within the canopy. In a study in England of the nest sites of another woodpecker species, Great Spotted Woodpecker Dendrocopos major, it was found that about half were in live trees and half in dead ones, but because dead trees were scarce in the study areas this represented a very strong selection for dead trees (Smith 1997).

Woodpeckers, in general, invest significant time and effort in making cavities, however, despite being morphologically adapted to excavate wood, they regularly select trees (dead or alive) that have soft and weak sections of timber owing to fungal heart rot, insect infestation or wounds from weather events (Matsuoka 2010, Lorenz et al. 2015). The tinder polypore found on many of the nest trees in this study $(80 \%$ were located just beneath this fungus) typically grows on snags and logs is often found in White-backed Woodpecker habitats. Indeed, some authors have suggested that it may have a certain relationship with the woodpecker (Urkijo-Letona et al. 2020). It seems highly likely that White-backed 
Woodpeckers prefer dead or highly decayed trees for nest sites, but due to insufficient data about the share of such trees in the vicinity of cavity trees, it was not possible to test this statistically for this study. Such trees are easier to excavate than healthy ones and provide convenient opportunities for cavity placement. Studies of species which are often sympatric with White-backed Woodpeckers in Europe, such as Black Woodpecker Dryocopus martius (Zahner et al. 2012), Grey-headed Woodpecker Picus canus (Gorman 2019), Eurasian Green Woodpecker Picus viridis (Gorman 2020b) and Great Spotted and Middle Spotted Woodpeckers Dendrocoptes medius (Kosiński \& Winiecki 2004), have all indicated that the hardness of the interior of trees is a major factor in cavity site selection. The Whitebacked Woodpeckers in this study were no exception, as ease of excavation was seemingly more important when selecting a cavity location rather than any relationship with specific tree species. Ultimately, providing the habitat surrounding potential nesting locations offers suitable foraging opportunities, almost any tree in a given area that is easy to excavate can be selected for cavities. This is in accordance with other studies on other European woodpeckers (Kosiński \& Winiecki 2004).

The heights of cavities found during this study were substantially lower than those documented in most other similar studies on the species. In the French Pyrenees mean heights $10 \mathrm{~m}$ (Grangé 1993), $13.7 \mathrm{~m}$ (Grangé et al. 2002) and $14.2 \mathrm{~m}$ (Grangé 2009) have been documented, and in Navarra, Spain, $11.1 \mathrm{~m}$ (Cárcamo et al. 2019). In an Italian study, the lowest nest was $5 \mathrm{~m}$ and the highest $28 \mathrm{~m}$ (Melletti \& Penteriani 2003). In Poland the lowest nest was $5 \mathrm{~m}$ and the highest $32 \mathrm{~m}$ (Wesołowski 1995), however, it might be noted that trees in Poland's old-growth forests can reach greater heights than in most other areas of Europe.

The widest diameter $(\mathrm{DBH})$ of a cavity tree recorded in this study was $55 \mathrm{~cm}$, the narrowest $35 \mathrm{~cm}$, with a mean of $41.6 \mathrm{~cm}$. This is remarkably similar to the mean of $42 \mathrm{~cm}$ recorded in a study of 43 nests in the Western Pyrenees, France (Grangé et al. 2002) and close to the $45.8 \mathrm{~cm}$ measured in a later study in the same region (Grangé 2009). Studies worldwide on the orientation of woodpecker cavity entrances have produced contrasting conclusions. A meta-analysis of cavity entrance orientation from 80 populations of 23 species of woodpecker throughout the Northern Hemisphere concluded that orientation was influenced by regional climatic conditions and was typically non-random (Landler et al. 2014). At present, there seems to have been no studies showing the adaptive advantages of particular nest orientations, but it is believed that they occur. Landler et al. (2014) included data from 12 studies on Great Spotted Woodpeckers and all but three of these studies found random orientation, the exceptions being studies in Great Britain (Tracy 1938), China (Wan et al. 2008) and Poland (Hebda 2009). In the present study of White-backed Woodpecker cavities across Hungary, orientation was non-random with a general alignment and southerly orientation of entrances prevailing. Similar studies on the species have either suggested that southward-facing cavity entrances are usual (Grangé 1993) or that compass direction was insignificant (Wesołowski 1995, Melletti \& Penteriani 2003, Grangé 2009, Cárcamo et al. 2019).

A study on Syrian Woodpeckers Dendrocopos syriacus (also carried out in Hungary) likewise found that south-facing cavity entrances prevailed (Gorman 2020a). Indeed, there is some evidence that in hill forests compass direction influences the location of cavity entrances to a greater extent than topographical factors such as slope gradients for 
White-backed Woodpeckers and Dendrocopos woodpeckers in general, birds tending to prefer south-facing slopes for nesting and also for foraging (Stenberg \& Hogstad 1992). The reasons for the predominance of southerly orientated cavities in this study are not obvious and several factors are likely to be implicated.

Thermophilic benefits from the southerly orientation of nest cavities may be involved. Nest cavities facing southwards receive more sunlight in the morning hours, hence increased light and warmth. In the breeding period, morning is the time when adults emerge from a night of incubation or brooding inside the nest chamber and begin to forage. The predominance of cavity entrances facing southwards seems to suggest that early morning warming is favoured by woodpeckers. As an example, a study of the Northern Flicker Colaptes auratus in North America found such an orientation to be associated with increased egg productivity, although this did not convert into breeding success (Wiebe 2001). However, Landler et al. (2014) identified a stronger southerly orientation selection for North American over Eurasian woodpeckers, thus factors other than latitude may influence selection in Hungary. For instance, prevailing wind direction in Hungary, which is from the northwest (Hungarian Meteorological Service undated), may be an influencing component. Yet, as with the positioning of cavities on trees, a compromise might occasionally be at work with local conditions resulting in some factors overriding others. For example, the southern sides of trees may not always receive the most sun owing to the immediate environment, as other trees or structures may create shade. In addition, woodpeckers may disregard compass direction when excavating a cavity if doing so involves substantial energy output. A section of the tree where a cavity can be more easily excavated may be selected, although it might not be ideal in terms of orientation. Wood facing away from the south may be selected because it is easier to excavate. Studies in subtropical forests of South America by Schaaf (2020) identified non-random orientation of cavities made by Dot-fronted Woodpecker Veniliornis frontalis which was related to differences in vegetation cover. Two orientations were identified, north and most protected by vegetation and north-west unprotected, and suggested the former orientation in maximum exposure to the sun hastened drying out of the microclimate around the cavity following intense rainfall. Conversely, the unprotected north-westerly orientation, which was out of the most intense period of sunlight, benefitted from afternoon accumulation of heat within the cavity to enhance the thermal properties inside during low night-time temperatures. Clearly, studies which look at the interactions between orientation and proportion of foliage cover, and other habitat attributes surrounding nest cavities, may be valuable and inform forest management.

The White-backed Woodpecker is an insectivorous forest specialist which nests in dying or dead trees and forages mainly on wood-boring beetles in the deadwood of deciduous species. It is therefore extremely sensitive to the changes in forest structure and composition that result from intensive forestry management (Virkkala et al. 1993, Fernández \& Azkona 1996, Martikainen et al. 1998, Mikusiński \& Angelstam 1998a, 1998b, Carlson 2000, Melletti \& Penteriani 2003). The White-backed Woodpeckers in this study were clearly dependent upon trees that were mature, dead, or in an advanced state of decay for nesting. Hence, as elsewhere across its range, the nesting and indeed overall habitat requirements of this species strongly indicate that intensive forest management methods should change. 
Forest managers should adopt close-to-nature methods which retain a diverse mix of tree age classes including standing deadwood and limit harvesting in protected areas. The incorporation of woodpecker richness and diversity measures should be used to inform forest management bodies (Lõhmus et al. 2016).

\section{Acknowledgements}

The author wishes to thank Danny Alder and Ken Smith for their valuable comments and suggestions which much improved this paper and for assistance with statistics. Thanks are also due to two anonymous reviewers.

\section{References}

Aulén, G. 1988. Ecology and distribution history of the White-backed Woodpecker Dendrocopos leucotos in Sweden. - Report No 14. Department of Wildlife Ecology, Swedish University of Agricultural Sciences, Uppsala

Aulén, G. \& Carlson, A. 1990. Demography of a declining White-backed Woodpecker population. - In: Carlson, A. \& Aulén, G. (eds.) Conservation and Management of Woodpecker Populations. - Swedish University of Agricultural Sciences, Department of Wildlife Ecology, Report 17. Uppsala, Sweden

Bernoni, M. 1995. Densita della popolazione di Picchio dorsobianco Picoides leucotos lilfordi nel Parco Nazionale d'Abruzzo [Population density of White-backed Woodpecker in the Abruzzo National Park]. - Avocetta 19: 130. (in Italian)

BirdLife International 2021. Species factsheet: Dendrocopos leucotos. - http://www.birdlife.org on 01/09/2021.

Bühler, U. 2021. Vorkommen des Weissrückenspechts Dendrocopos leucotos und Waldnutzung in Nordbünden [Occurrence of White-backed Woodpecker Dendrocopos leucotos and forest use in northern Grisons]. Ornithologischer Beobachter 118: 58-75. (in German with English Summary)

Cárcamo, S., Elosegi, M. M., Senosiain, A. \& Arizaga, J. 2019. Nidotópica y parámetros reproductivos en el pico dorsiblanco Dendrocopos leucotos lilfordi Sharpe \& Dresser, 1871 en Navarra [Nest site selection and reproduction parameters in the White-backed Woodpecker Dendrocopos leucotos lilfordi Sharpe \& Dresser, 1871 in Navarre]. - Munibe Ciencias Naturales 67: 31-44. DOI: 10.21630/mcn.2019.67.06 (in Spanish with English Summary)

Carlson, A. 2000. The effect of habitat loss on a deciduous forest specialist: the White-backed Woodpecker (Dendrocopos leucotos). - Forest Ecology and Management 131(1): 215-221. DOI: 10.1016/S03781127(99)00215-7

Costantini, C. \& Melletti, M. 1992. The White-backed Woodpecker, Picoides leucotos lilfordi, and the Lesser Spotted Woodpecker, Picoides minor, in the beech woods of the Simbruini and Ernici Mountains (Central Italy). - Rivista Italiana di Ornitologia 62: 164-170.

Czeszczewik, D. 2009. Foraging behaviour of White-backed Woodpeckers Dendrocopos leucotos in a primeval forest (Białowieża National Park, NE Poland): Dependence on habitat resources and season. - Acta Ornithologica 44: 109-118. DOI: 10.3161/000164509X482687

del Hoyo, J. \& Collar, N. J. 2014. HBW and BirdLife International Illustrated Checklist of the Birds of the World, Vol. 1. Non-passerines. - Lynx Edicions, Barcelona

Dement'ev, G. P. \& Gladkov, N. A. 1966. (eds.) Birds of the Soviet Union. Vol. 1. - Israel Program for Scientific Translations, Jerusalem

Fernández, C. \& Azkona, P. 1996. Influence of forest structure on the density and distribution of the White-backed Woodpecker Dendrocopos leucotos and Black Woodpecker Dryocopus martius in Quinto Real (Spanish western Pyrenees). - Bird Study 43: 305-313. DOI: 10.1080/00063659609461023

Frank, G. 2002. Brutzeitliche Einnischung des Weissrückenspechtes Dendrocopos leucotos im Vergleich zum Buntspecht Dendrocopos major in montanen Mischwäldern der nordlichen Kalkalpen [Habitat selection of 
White-backed Woodpecker Dendrocopos leucotos during the breeding season in comparison to Great Spotted Woodpecker Dendrocopos major in mountainous mixed forests of the northern Austrian Chalk Alps]. Vogelwelt 123: 225-239. (in German)

Garmendia, A., Cárcamo, S. \& Schwendtner, O. 2006. Forest management considerations for conservation of Black Woodpecker Dryocopus martius and White-backed Woodpecker Dendrocopos leucotos populations in Quinto Real (Spanish Western Pyrenees). - Biodiversity and Conservation 15: 339-355. DOI: 10.1007/ s10531-005-5410-0

Gerdzhikov, G. P., Georgiev, K. B., Plachiyski, D. G., Zlatanov, T. \& Shurulinkov, P. S. 2018. Habitat requirements of the White-backed Woodpecker Dendrocopos leucotos lilfordi (Sharpe \& Dresser, 1871) (Piciformes: Picidae) in Strandzha Mountain, Bulgaria. - Acta Zoologica Bulgarica 70: 527-534.

Gorman, G. 1995. Identifying the presence of woodpecker (Picidae) species on the basis of their holes and signs. - Aquila 102: 61-67.

Gorman, G. 2014. Woodpeckers of the World: The Complete Guide. - Helm, London, UK

Gorman, G. 2019. Characteristics of Grey-headed Woodpecker (Picus canus) cavities in Hungary. - Aquila 126: $33-39$.

Gorman, G. 2020a Details of cavities used by Syrian Woodpeckers Dendrocopos syriacus in Hungary. - Bird Study 67(2): 251-255. DOI: 10.1080/00063657.2020.1808588

Gorman, G. 2020b Attributes of Eurasian Green Woodpecker (Picus viridis) nest cavities in Hungary. - Ornis Hungarica 28(2): 204-211. DOI: 10.2478/orhu-2020-0025

Gorman, G., Komlós, M., Ónodi, G. \& Schmidt, A. 2021. Fehérhátú fakopáncs Dendrocopos leucotos White-backed Woodpecker. - In: Szép, T., Csörgő, T., Halmos, G., Lovászi, P., Nagy, K. \& Schmidt, A. (eds.) Magyarország madáratlasza - Bird Atlas of Hungary. - Agrárminisztérium, Magyar Madártani és Természetvédelmi Egyesület, Budapest, pp. 428-429. https://mme.hu/birdatlas (in Hungarian with English Summary)

Grangé, J-L. 1993. Donnees preliminaires sur la biologie de reproduction du Pic a dos blanc pyreneen (Dendrocopos leucotos lilfordi) en Bearn [Preliminary data on the reproductive biology of the Pyrenian White-backed Woodpecker (Dendrocopos leucotos lilfordi) in Bearn]. - Nos Oiseaux 42: 17-28. (in French)

Grangé, J-L., Auria, J-C., André, C. \& Navarre, P. 2002. Biologie de reproduction du Pic à dos blanc Dendrocopos leucotos lilfordi dans les Pyrénées occidentales (France) [Reproductive biology of the White-backed Woodpecker Dendrocopos leucotos lilfordi in the Western Pyrenees, France]. - Nos Oiseaux 49: 199-212. (in French with English Summary).

Grangé, J-L. 2009. Caractéristiques des arbres de nid chez le Pic à dos blanc Dendrocopos leucotos lilfordi dans les Pyrénées occidentales françaises [Characteristics of the trees in which the White-backed Woodpecker Dendrocopos leucotos lilfordi nests in the French western Pyrenees]. - Le Casseur d'Os 9: 92-110. (in French with English Summary).

Grangé, J-L. 2016. Breeding biology of the Lilford Woodpecker Dendrocopos leucotos lilfordi in the Western Pyrenees (SW France). - Denisia 36 Zugleich Kataloge des Oberösterreichischen Landesmus 164: 99-111.

Grangé, J-L., Senosiain, A., Marsaguet, P. \& Navarre, P. 2020. Creusement de cavités en automne-hiver par les Picidés européens [Excavation of cavities by European woodpeckers in autumn-winter]. - Ornithos 27(6): 345-354. (in French with English Summary)

Hågvar, S., Hågvar, G. \& Mønness, E. 1990. Nest site selection in Norwegian woodpeckers. - Holarctic Ecology 13:156-165. DOI: $10.1111 / \mathrm{j} .1600-0587.1990 . t b 00602 . x$

Håland, A. \& Ugelvik, M. 1990. The status of the White-backed Woodpecker Dendrocopos leucotos in Norway. - In: Carlson, A. \& Aulén, G. (eds.) Conservation and Management of Woodpecker Populations. - Swedish University of Agricultural Sciences, Department of Wildlife Ecology, Report 17. Uppsala, Sweden

Hämäläinen, K., Junninen, K., Halme, P. \& Kouki, J. 2020. Managing conservation values of protected sites: how to maintain deciduous trees in White-backed Woodpecker territories. - Forest Ecology and Management 461: 117946. DOI: $10.1016 /$ j.foreco.2020.117946

Håpnes, A. 2003. The White-backed Woodpecker, highly threatened by forestry. - WWF-Norway

Hebda, G. 2009. Nesting sites of the Great Spotted Woodpecker Dendrocopos major L. in Poland: analysis of nest cards. - Polish Journal of Ecology 57: 149-158.

Hogstad, O. \& Stenberg, I. 1994. Habitat selection of a viable population of White-backed Woodpeckers Dendrocopos leucotos. - Journal für Ornithologie 138: 25-38.

Hungarian Meteorological Service. Undated. Wind conditions of Hungary. - https://www.met.hu/en/eghajlat/ magyarorszag_eghajlata/altalanos_eghajlati_jellemzes/szel/. Accessed 01/09/2021. 
Kosiński, Z. \& Winiecki, A. 2004. Nest-site selection and niche partitioning among the Great Spotted Woodpecker Dendrocopos major and Middle Spotted Woodpecker Dendrocopos medius in riverine forest of Central Europe. - Ornis Fennica 81: 145-156.

Krams, I. 1998. Nest site selection of the White-backed Woodpecker Dendrocopos leucotos in the eastern part of Latvia. - Ornis Svecica 8: 11-16.

Landler, L., Jusino, M. A., Skelton, J. \& Walters, J. R. 2014. Global trends in woodpecker cavity entrance orientation: latitudinal and continental effects suggest regional climate influence. - Acta Ornithologica 49: 257-266. DOI: 10.3161/173484714X687145

Lanz, M., Keiss, O. \& Keller, V. 2020. Dendrocopos leucotos White-backed Woodpecker. - In: Keller, V., Herrando, S., Voříšek, P., Franch, M., Kipson, M., Milanesi, P., Martí, D., Anton, M., Klvaňová, A., Kalyakin, M. V., Bauer, H-G. \& Foppen, R. P. B. 2020. European Breeding Bird Atlas 2: Distribution, Abundance and Change. - European Bird Census Council and Lynx Edicions, Barcelona

Lorenz, T. J., Vierling, K. T., Johnson, T. R. \& Fischer, P. C. 2015. The role of wood hardness in limiting nest site selection in avian cavity excavators. - Ecological Applications 25(4): 1016-1033. DOI: 10.1890/14-1042.1

Lõhmus, A., Nellis, R., Pullerits, M. \& Leivits, M. 2016. The potential for long-term sustainability in seminatural forestry: a broad perspective based on woodpecker populations. - Environmental Management 57(3): 558571. DOI: $10.1007 / \mathrm{s} 00267-015-0638-2$

Lund, U. \& Agostinelli, C. 2011. Package 'circular': circular statistics. - R package version 0.4-3.

Martikainen, P., Kaila, L. \& Haila, Y. 1998. Threatened beetles in White-backed Woodpecker habitats. Conservation Biology 12(2): 293-301. DOI: 10.1111/j.1523-1739.1998.96484.x

Matsuoka, S. 2010. Great Spotted Woodpeckers Dendrocopos major detect variation in wood hardness before excavating nest holes. - Ornithological Science 9(1): 67-74. DOI: 10.2326/osj.9.67

Melletti, M. \& Penteriani, V. 2003. Nesting and feeding tree selection in the endangered White-backed Woodpecker, Dendrocopos leucotos lilfordi. - Wilson Bulletin 115(3): 299-306. DOI: 10.1676/03-022

Mikusiński, G. \& Angelstam, P. 1998a Economic geography, forest distribution and woodpecker diversity in central Europe. - Conservation Biology 12: 200-208. DOI: 10.1111/j.1523-1739.1998.96310.x

Mikusiński, G. \& Angelstam, P. 1998b European woodpeckers and anthropogenic habitat change: evidence of effects in different scales. - Vogelwelt 118: 277-283.

Pavelka, K. 2003. Strakapoud Belohrbety (Dendrocopos leucotos) v zapadnich Beskydech a Javornikach [Whitebacked Woodpecker in the Western Beskydy Mountains and in the Javorniky Mountains]. - Crex 21: 39-46. (in Czech with English Summary)

Pavlík, Š. 1999. Breeding ecology of the White-backed Woodpecker Dendrocopos leucotos in oak forest. Biologia 54: 187-194.

Pewsey, A., Neuhauser, M. \& Ruxton, G. D. 2013. Circular Statistics in R. - OUP, Oxford

Pons, J-M., Campión, D., Chiozzi, G., Ettwein, A., Grangé, J-L., Kajtoch, L., Mazgajski, T. D., Rakovic, M., Winkler, H. \& Fuchs, J. 2021. Phylogeography of a widespread Palaearctic forest bird species: The Whitebacked Woodpecker (Aves, Picidae). - Zoologica Scripta 50: 155-172. DOI: 10.1111/zsc.12466

R Development Core Team 2015. R: A language and environment for statistical computing. - R Foundation for Statistical Computing, Vienna, Austria

Roberge, J. M., Mikusiński, G. \& Svensson, S. 2008. The White-backed Woodpecker: Umbrella species for forest conservation planning? - Biodiversity and Conservation 17: 2479-2494. DOI: 10.1007/s10531-008-9394-4

Sabatini, F. M., Burrascano, S., Keeton, W. S., Levers, Ch., Lindner, M., Pötzschner, F., Verkerk, P. J., Bauhus, J., Buchwald, E., Chaskovsky, O., Debaive, N., Horváth, F., Garbarino, M., Grigoriadis, N., Lombardi, F., Duarte, I. M., Meyer, P., Midteng, R., Mikac, S., Mikoláš, M., Motta, R., Mozgeris, G., Nunes, L., Panayotov, M., Ódor, P., Ruete, A., Simovski, B., Stillhard, J., Svoboda, M., Szwagrzyk, J., Tikkanen, O-P., Volosyanchuk, R., Vrska, T., Zlatanov, T. \& Kuemmerle, T. 2018. Where are Europe's last primary forests? - Diversity and Distributions 24: 1426-1439. DOI: 10.1111/ddi.12778

Schaaf, A. A. 2020. Effects of sun exposure and vegetation cover on Woodpecker nest orientation in subtropical forests of South America. - Journal of Ethology 38(1): 117-120. DOI: 10.1007/s10164-019-00617-2

Scherzinger, W. 1990. Is competition by the Great Spotted Woodpecker the cause for White-backed Woodpecker's rarity in Bavarian Forest National Park? - In: Carlson, A. \& Aulén, G. (eds.) Conservation and management of woodpecker populations, report 17 (Swedish University of Agricultural Sciences, Department of Wildlife Ecology, Uppsala, Sweden) pp. 81-91.

Schwaiger, S. \& Lauterbach, M. 2019. Verbreitung, Bestandssituation und Habitatansprüche von Dreizehenspecht Picoides tridactylus Und Weißrückenspecht Dendrocopos leucotos in den Bayerischen Alpen [Distribution, 
population density and habitat requirements of Three-toed Woodpecker (Picoides tridactylus) and Whitebacked Woodpecker (Dendrocopos leucotos) in the Bavarian Alps]. - Ornithologischer Anzeiger 57: 228-242. (in German with English Summary)

Smith, K. 1997. Nest site selection of the Great Spotted Woodpecker Dendrocopos major in two oak woods in southern England and its implications for woodland management. - Biological Conservation 80: 283-288. DOI: $10.1016 / \mathrm{S} 0006-3207(96) 00038-9$

Stenberg, I. \& Hogstad, O. 1992. Habitat use and density of breeding woodpeckers in the 1990s in Møre og Romsdal county, western Norway. - Fauna Norvegica, Serie C, Cinclus 19: 21-38.

Szmorad, F., Frank, T. \& Korda, M. 2018. Erdőgazdálkodás és erdőkezelés Natura 2000 területeken. Natura 2000 kézikönyv erdőgazdálkodóknak [Forestry and forest management in Natura 2000 areas. Natura 2000 handbook for forest managers]. - Duna-Ipoly Nemzeti Park Igazgatóság, Budapest (in Hungarian)

Tracy, N. 1938. Der grosse Buntspecht [The Great Spotted Woodpecker]. - Beiträge zur Fortpflanzungsbiologie der Vögel 14: 41-48. (in German)

Urkijo-Letona, A., Cárcamo, S., Peña, L., Fernández de Manuel, B., Onaindia, M. \& Ametzaga-Arregi, I. 2020. Key elements of the White-backed Woodpecker's (Dendrocopos leucotos lilfordi) habitat in its European South-Western limits. - Forests 11: 831. DOI: 10.3390/f11080831

Virkkala, R., Alanko, T., Laine, T. \& Tiainen, J. 1993. Population contraction of the White-backed Woodpecker Dendrocopos leucotos in Finland as a consequence of habitat alteration. - Biological Conservation 66: 47-53.

Wan, T., Hu, J-F., Jiao, Z-B., Wen, J-B. \& Luo, Y-Q. 2008. Nest-cavity characteristics of the Great Spotted Woodpecker Dendrocopos major in shelter plantations of west Inner Mongolia. - Forestry Studies in China 10: 36-40. DOI: 10.1007/s11632-008-0010-1

Wesołowski, T. \& Tomiałojć, L. 1986. The breeding ecology of woodpeckers in a temperate primeaval forest preliminary data. - Acta Ornithologica 22: 1-21.

Wesołowski, T. 1995. Ecology and Behaviour of White-backed Woodpecker (Dendrocopos leucotos) in a primaeval temperate forest (Białowieża National Park, Poland). - Vogelwarte 38: 61-75.

Wesołowski, T., Hebda, G. \& Rowiński, P. 2021. Variation in timing of breeding of five woodpeckers in a primeval forest over 45 years: role of food, weather, and climate. - Journal of Ornithology 162: 89-108. DOI: 10.1007/ s10336-020-01817-1

Wiebe, K. L. 2001. Microclimate of tree cavity nests: is it important for reproductive success in Northern Flickers? - The Auk 118: 412-421. DOI: 10.1093/auk/118.2.412

Zahner, V., Sikora, L. \& Pasinelli, G. 2012. Heart rot as a key factor for cavity tree selection in the Black Woodpecker. - Forest Ecology and Management 271: 98-103. DOI: 10.1016/j.foreco.2012.01.041

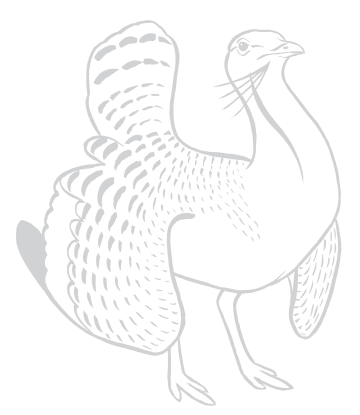

